\title{
Effects of Poultry Manure, Kitchen Waste Compost and NPK Fertilizer on Growth and Yield of Ladies Finger
}

\author{
M. G. Kibria ${ }^{1}$, N. Hossain ${ }^{2}$, M. J. Ahammad ${ }^{3}$ and K. T. Osman ${ }^{4}$ \\ 1, 2,3,4 Department of Soil Science, University of Chittagong, Chittagong 4331, Bangladesh
}

\begin{abstract}
A field experiment was conducted to study the effects of poultry manure, kitchen waste compost and NPK fertilizer on growth and yield of ladies finger (Abelmoschus esculentus L Moench) in the crop field of the Department of Soil Science, University of Chittagong, Bangladesh during April-August, 2011. There were six treatments- control (no fertilizer/poultry manure/compost), full NPK @ $120 \mathrm{~kg} \mathrm{Nh}^{-1}, 60 \mathrm{~kg} \mathrm{Pha}$ and $80 \mathrm{~kg} \mathrm{~K}$ $h^{-1}$, full poultry manure (PM) @ 30 ton ha ${ }^{-1}, 50 \%$ NPK+ 50\% PM, full kitchen waste compost @ 30 ton ha ${ }^{-1}$, and $50 \% \mathrm{NPK}+50 \%$ compost. The treatments were arranged in randomized block design with three replications. The data collected were number of leaves, plant height, fruit length, fruit circumference, number of fruits and fruit yield. The results showed that full NPK fertilizer did not increase the growth and yield of ladies finger over control. Application of poultry manure, compost and their combination with NPK fertilizers significantly influenced the growth and yield. However, the combined application of 50\% NPK+50\% PM showed the best ladies finger performance compared to other treatments in the valley soils of Chittagong.
\end{abstract}

Key words: poultry manure, kitchen compost, ladies finger, growth, yield.

\section{Introduction}

Vegetables play a vital role in the improvement of the diet of mankind. Ladies finger (Abelmoschus esculentus L Moench) is one of the most important edible and nutritious vegetable crops in Bangladesh. It belongs to the family Malvaceae, originating from tropical and subtropical Africa. The nutritional constituents of ladies finger include carbohydrate, protein, phosphorus, calcium, magnesium, iron, vitamin $\mathrm{A}$ and $\mathrm{C}$ with traces of vitamin B [1,2, and 3]. Ladies finger is a fruit vegetable, grown mainly for the pods. The tender fruits are used as vegetables either boiled or sliced and fried. Ladies finger pod contains $8.20 \%$ carbohydrates, 2.10 $\%$ protein and a significant amount of riboflavin [4]. Ripe seeds contain edible oil that could be as high as poultry eggs and soybean [5]. The leading ladies finger producing countries are India, Sudan, Egypt and Nigeria [6]. Ladies finger production is very low in many developing countries. Although ladies finger is very much popular in Bangladesh, the yield of the crop is as low as 3.11 ton ha $^{-1}$ [7]. On the other hand, the yield of ladies finger varied from 11 to 15 ton ha ${ }^{-1}$ from region to region [8]. Now it is well agreed that depleted soil fertility is a major constraint for higher crop production in Bangladesh and indeed, yield of several crops are declining in some soils [9]. Optimum production of ladies finger requires intensive management practices that conserve and manage soil and nutrient needed for maintaining soil and water quality. Both fertilizers and manures have a potential role on crop growth and development. But indiscriminate use of inorganic fertilizer changes physical, chemical and biological properties of soil as well as reduces the fertility status of soil. Chemical fertilizers are costly too and are not always affordable to poor farmers [10]. This necessitates research into organic wastes that are cheap, readily available and environmentally friendly that can be used as fertilizer. Organic matter is the ultimate determinant of the soil fertility in most tropical soils. Organic matter content of in the soil of Bangladesh is below $1 \%$ in about $60 \%$ of cultivable lands compared to an ideal minimum value of $3 \%$ [11] Maintenance of soil fertility is a prerequisite for long term sustainable agriculture and organic manures play a vital role in maintaining soil fertility and crop production. According to Olatunji et al. [12], the application of organic manure had been found to have higher comparative economic advantage over the use of inorganic fertilizer. Organic manure helps to improve physical condition of soil and provide adequate amounts of necessary nutrients for the soil productivity. Corrale et al. [13] observed that yield advantages accruing from the application of inorganic fertilizers but cautioned on the negative influence of their cost and availability results on the popularity of organic materials as means of supplementing native soil fertility in tropical areas. Poultry manure and kitchen compost can serve as suitable alternates to chemical fertilizers. Poultry manure is a good source of major and minor mineral elements that are capable of enhancing soil fertility [14]. The fertility of soil could be sustained with the addition of poultry manure [15]. Poultry manure contains high percentage of nitrogen and phosphorus for the healthy growth of plants 16]. Compost helps to optimize nutrient management and the land application of compost may contribute to combat soil organic matter decline and soil erosion [17]. Materials which are typically suitable for composting include kitchen waste and biodegradable municipal waste, plus other enriched organic waste streams, such as sewage sludge, agricultural, and food processing wastes [18]. 
Compost application to agricultural land needs to be carried out in a manner that ensures sustainable development.

Management systems have to be developed to enable to maximize agronomic benefit, whilst ensuring the protection of environmental quality. Sustainable agriculture is a system of food production which avoids or largely excludes the use of systematically compounded chemical fertilizers and pesticides and use of environmentally friendly organic inputs. The integrated use of organic and inorganic fertilizers may be a sound soil fertility management strategy in many countries. Recently there has been boost in poultry production in Bangladesh which leads to piling of poultry wastes. This constitutes environmental pollution and health hazards. However, research information is scarce on response of ladies finger's growth and yield to application of poultry manure and kitchen compost in the valley soils of Chittagong, Bangladesh. Hence, the objective of this work was to determine the effects of poultry manure and kitchen compost on growth and yield of ladies finger relative to the recommended level of NPK fertilizer in the valley soils of Chittagong.

\section{Materials And Methods}

\section{1. Field experiment}

A field experiment was conducted to study the effects of poultry manure, kitchen compost and NPK fertilizers on growth and yield of ladies finger (Abelmoschus esculentus L (Moench) during April- August, 2011 in the Crop Field of the Department of Soil Science, University of Chittagong. For the study, poultry manure was obtained from nearby poultry farms. Separately compost was prepared from kitchen wastes collected from some of the University Halls. Eighteen experimental plots $(2.2 \mathrm{~m}$ x $2.2 \mathrm{~m})$ separated by $0.5 \mathrm{~m}$ margins were prepared in three adjacent blocks in the crop field. There were six plots in each block for the six treatment combinations comprising of poultry manure (PM), kitchen compost and NPK fertilizers as follows-

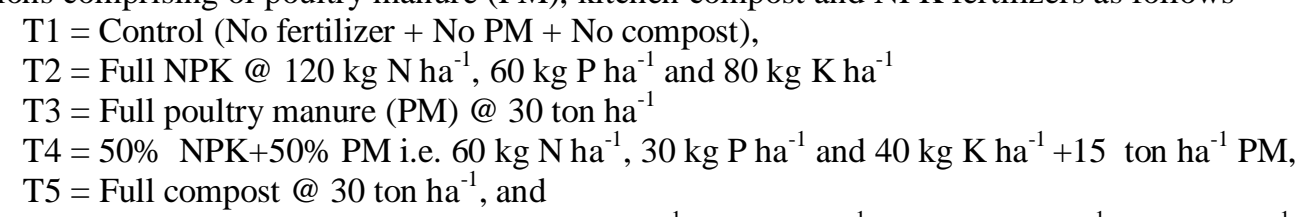

T6 $=50 \%$ NPK $+50 \%$ compost i.e. $60 \mathrm{~kg} \mathrm{~N} \mathrm{ha}^{-1}, 30 \mathrm{~kg} \mathrm{Pha}^{-1}$ and $40 \mathrm{~kg} \mathrm{~K} \mathrm{ha}^{-1}+15$ ton ha ${ }^{-1}$ compost.

The treatments were arranged according to a randomized complete block design. Nitrogen in the form of urea was applied in 3 splits according to BARC [19] recommendation. One-third of nitrogen fertilizer (i.e. urea) was applied as basal dose before sowing, the $2^{\text {nd }}$ dose was given after one month of sowing and the third installment was given at the flowering stage. Phosphorus and potassium fertilizers were also applied as basal at the final stage of soil preparation. All of poultry manure and kitchen composts were applied as basal during soil preparation and soils mixed with poultry manure and compost were allowed to equilibrate for 4 weeks prior to sowing seeds.

Ladies finger variety BARIdheros-1 released by Bangladesh Agricultural Research Institute was used in the experiment. The seeds were sown in lines $60 \mathrm{~cm}$ apart with seed to seed distance of $45 \mathrm{~cm}$. In each point two seeds were sown. Seedlings emerged after 4 to 5 days of sowing. One healthy seedling was retained in each point. Irrigation was applied as and when necessary. The experimental plot was kept free of weeds by regular weeding. To control the pests and diseases, necessary plant protection measures were done as and when required.

\section{2. Data collection}

Plant height and number of leaves were recorded at 15,30, 45, 60 and 75 days after seedling emergence (DAS) to assess plant growth. The fruits were harvested at 3 days interval. Length of fruit, fruit circumference, numbers and fresh weights of fruit were recorded. Yield was computed based on the cumulative numbers and fresh weights of fruit at 15 harvests. Dry weights of shoot and root were recorded after final harvest at maturity.

\section{3. Properties of soil, poultry manure and kitchen compost}

Soil texture was determined by hydrometer method [20], soil $\mathrm{pH}$ was measured in a 1:2.5 soil/water suspension with glass electrode $\mathrm{pH}$ meter, organic carbon by wet-oxidation method [21], total nitrogen by micro-Kjeldahl digestion and distillation and $\mathrm{CEC}$ by $1 \mathrm{~N} \mathrm{NH}_{4} \mathrm{OAC}$ saturation [22], and available phosphorus by Olsen method [23].The same methods used for soil were followed for the determination of properties of poultry manure and kitchen compost. The experimental soil was clay loam (33\% sand, $19 \%$ silt and $48 \%$ clay) with pH 5.10 , organic matter content $1.32 \%$, cation exchange capacity (CEC) $8.76 \mathrm{cmol} \mathrm{kg}^{-1}$, total nitrogen $0.12 \%$, and available $\mathrm{P}(\mathrm{Olsen} \mathrm{P}) 14 \mathrm{mg} \mathrm{kg}^{-1}$. Poultry manure used in the experiment contained $\mathrm{pH} 7.65$, total nitrogen 0.28 $\%$, available $\mathrm{P} 14.17 \mathrm{mg} \mathrm{kg}^{-1}$. Kitchen compost with $\mathrm{pH} 8.35$ contained total nitrogen $0.15 \%$, available P 4.77 $\mathrm{mg} \mathrm{kg}^{-1}$. 


\section{4. Statistical analysis}

The significance of differences between the means of the treatments was evaluated by one way analysis of variance followed by Duncan's Multiple Range Test at the significance level of 5\%. The statistical software Excel [24] and SPSS version 12 [25] were used for these analyses.

\section{1. Growth of ladies finger}

\section{Results And Discussion}

The number of leaves plant $^{-1}$ was the minimum in the control (T1) and the maximum in $50 \%$ NPK $+50 \%$ PM (T4) in the periods of recording at 30, 45, 60 and 75 DAS (Table 1). Application of full NPK (T2) did not increase number of leaves plant ${ }^{-1}$ compared to control. Full poultry manure (T3) significantly increased number of leaves plant ${ }^{-1}$ over control at 30 and 45 DAS but not at 60 and 75 DAS. Similar result was found with $50 \% \mathrm{NPK}+50 \%$ compost (T6). Number of leaves plant ${ }^{-1}$ with $50 \% \mathrm{NPK}+50 \% \mathrm{PM}$ (T4) was significantly higher than that with control (T1) and full NPK fertilizer (T2) at 30, 45 and 75 DAS. However, the number of leaves plant ${ }^{-1}$ in treatments T3 (full PM), T4 (50\% NPK+ 50\% PM), T5 (full compost)) and T6 (50\% $\mathrm{NPK}+50 \%$ compost) were statistically similar with each other at 15, 30, 45 and 60 DAS.

Table 1. Effects of poultry manure, kitchen compost and NPK fertilizer on number of leaves of ladies finger at different growth period.

\begin{tabular}{clllll}
\hline & \multicolumn{5}{c}{ Number of leaves plant ${ }^{-1}$} \\
\cline { 2 - 6 } Treatment & 15 DAS & 30 DAS & 45 DAS & 60 DAS & 75 DAS \\
\hline T1 & $7.33 \mathrm{a}$ & $30.67 \mathrm{c}$ & $36.00 \mathrm{~b}$ & $54.33 \mathrm{~b}$ & $55.33 \mathrm{~b}$ \\
T2 & $7.33 \mathrm{a}$ & $32.67 \mathrm{bc}$ & $39.33 \mathrm{~b}$ & $69.00 \mathrm{ab}$ & $67.33 \mathrm{~b}$ \\
T3 & $7.67 \mathrm{a}$ & $39.33 \mathrm{ab}$ & $59.67 \mathrm{a}$ & $84.00 \mathrm{ab}$ & $82.33 \mathrm{~b}$ \\
T4 & $8.00 \mathrm{a}$ & $42.00 \mathrm{a}$ & $66.33 \mathrm{a}$ & $98.33 \mathrm{a}$ & $116.00 \mathrm{a}$ \\
T5 & $7.33 \mathrm{a}$ & $37.67 \mathrm{abc}$ & $61.67 \mathrm{a}$ & $90.00 \mathrm{a}$ & $66.00 \mathrm{~b}$ \\
T6 & $8.00 \mathrm{a}$ & $41.67 \mathrm{a}$ & $65.00 \mathrm{a}$ & $76.33 \mathrm{ab}$ & $81.33 \mathrm{~b}$ \\
Sig. of F value & NS & 0.05 & 0.001 & 0.05 & 0.01 \\
\hline
\end{tabular}

Mean values in a column followed by the same letter $(\mathrm{s})$ are not significantly different by DMRT $(\mathrm{p}<0.05)$.

NS= Not Significant.

Height of plants varied from 17.67 (T1) to 22.33 (T3) at 15 DAS, 64.33 (T1) to 85.33 (T3) at 30 DAS, 98.33 (T1) to 134.00 (T4) at 45 DAS, 147.00 (T1) to 185.33 (T3) at 60 DAS and 179.67 (T1) to 224.00 (T4) at 75 DAS (Table 2). Thus, the minimum was always obtained in the control treatment and the maximum values were obtained with full poultry manure at 15, 30 and 60 DAS and with $50 \% \mathrm{NPK}+50 \% \mathrm{PM}$ at 45 and 75 DAS. There was no significant difference in values of plant height between control and full NPK fertilizer in any period of recording at 15, 30, 45, 60 and 75 DAS. Addition of full poultry manure (T3) significantly increased height of plants in all the periods. In full poultry manure, the values were 22.33 at $15 \mathrm{DAS}, 85.33 \mathrm{~cm}$ at 30 DAS, $131.00 \mathrm{~cm}$ at 45 DAS, $185.33 \mathrm{~cm}$ at 60 DAS and $223.33 \mathrm{~cm}$ at 75 DAS. Application of $50 \% \mathrm{NPK}+50 \%$ PM (T4) gave significantly higher plant height than control (T1) and full NPK (T2) at 30, 45 and 75 DAS. However, values of plant height between full PM (T3) and 50\% NPK+50\% PM (T4) were statistically similar. Full compost (T5) significantly increased plant height at 30 and 45 DAS but not at 15, 60 and 75 DAS. Application of 50\% NPK+50\% compost increased plant height significantly to $83.33 \mathrm{~cm}, 129.67 \mathrm{~cm}$ and 175.67 $\mathrm{cm}$ at 30, 45 and 60 DAS. Values of plant height between full compost and 50\% NPK+50\% compost were statistically similar. There were no significant differences among the treatments of full NPK (T2), full compost (T5) and 50\% NPK $+50 \%$ compost (T6) in producing height of plant except between full NPK (T2) and 50\% $\mathrm{NPK}+50 \%$ compost (T6) at 30DAS.

Table 2. Effects of poultry manure, kitchen compost and NPK fertilizer on plant height at different growth periods and dry matter production at maturity of ladies finger.

\begin{tabular}{clllllll}
\hline & \multicolumn{5}{c}{ Plant height $(\mathrm{cm})$} & \multicolumn{3}{c}{ Dry weight $\left(\mathrm{g} \mathrm{plant}^{-1}\right)$} \\
\cline { 2 - 8 } Treatment & $15 \mathrm{DAS}$ & $30 \mathrm{DAS}$ & $45 \mathrm{DAS}$ & $60 \mathrm{DAS}$ & $75 \mathrm{DAS}$ & Shoot & Root \\
\hline T1 & $17.67 \mathrm{~b}$ & $64.33 \mathrm{c}$ & $98.33 \mathrm{c}$ & $147.00 \mathrm{~b}$ & $179.67 \mathrm{~b}$ & $60.30 \mathrm{~b}$ & $11.91 \mathrm{c}$ \\
T2 & $18.67 \mathrm{ab}$ & $71.00 \mathrm{bc}$ & $111.00 \mathrm{bc}$ & $160.00 \mathrm{ab}$ & $180.00 \mathrm{~b}$ & $59.81 \mathrm{~b}$ & $26.72 \mathrm{~b}$ \\
T3 & $22.33 \mathrm{a}$ & $85.33 \mathrm{a}$ & $131.00 \mathrm{ab}$ & $185.33 \mathrm{a}$ & $223.33 \mathrm{a}$ & $122.30 \mathrm{a}$ & $39.20 \mathrm{ab}$ \\
T4 & $21.67 \mathrm{ab}$ & $80.67 \mathrm{a}$ & $134.00 \mathrm{a}$ & $183.67 \mathrm{a}$ & $224.00 \mathrm{a}$ & $133.74 \mathrm{a}$ & $44.81 \mathrm{a}$ \\
T5 & $19.67 \mathrm{ab}$ & $77.33 \mathrm{ab}$ & $125.00 \mathrm{ab}$ & $170.67 \mathrm{ab}$ & $203.67 \mathrm{ab}$ & $107.82 \mathrm{ab}$ & $33.94 \mathrm{ab}$ \\
T6 & $20.00 \mathrm{ab}$ & $83.33 \mathrm{a}$ & $129.67 \mathrm{ab}$ & $175.67 \mathrm{a}$ & $202.00 \mathrm{ab}$ & $81.35 \mathrm{ab}$ & $42.10 \mathrm{a}$ \\
Sig. of F value & 0.05 & 0.01 & 0.01 & 0.05 & 0.05 & 0.05 & 0.001 \\
\hline
\end{tabular}

Mean values in a column followed by the same letter (s) are not significantly different by DMRT $(\mathrm{p}<0.05)$ 
Oven dry weight of shoot at maturity ranged from 59.81 to $133.74 \mathrm{~g} \mathrm{plant}^{-1}$ (Table 2). The highest shoot weight $(133.74 \mathrm{~g})$ was found with T4 $(50 \% \mathrm{NPK}+50 \% \mathrm{PM})$ treatment and the lowest shoot weight $(59.81 \mathrm{~g})$ was found with T2 (full NPK) treatment. Shoot weight in treatments T3 (full PM) and T4 (50\% NPK+50\% PM) was significantly higher than that in T1 (control) and T2 (full NPK). However, there was no significant difference between the treatments T3 (122.30 g; full PM) and T4 (133.74; 50\% NPK+ 50\% PM). Treatment T2 $(59.81 \mathrm{~g}), \mathrm{T} 5(107.82 \mathrm{~g})$ and T6 $(81.35 \mathrm{~g})$ were statistically similar with treatment T1 $(60.30 \mathrm{~g}$; control) and are not significantly different from each other though these treatments were either individual or combination of NPK fertilizer and compost.

Oven dry weight of root varied from 11.91 (T1; control) to $44.81(\mathrm{~T} 4 ; 50 \% \mathrm{NPK}+50 \% \mathrm{PM}) \mathrm{g} \mathrm{plant}^{-1}$ (Table 2). Poultry manure, compost and NPK fertilizer treatments produced significantly higher root weight than control treatment (T1). However, full NPK fertilizer (T2), full poultry manure (T4) and full compost (T5) was not significantly different from each other. Treatment T4 (50 NPK+50\% PM) and T6 (50\% NPK+50\% compost) was also statically similar. Poultry manure and compost in combination with NPK fertilizer gave significantly higher root weight than full NPK fertilizer alone.

\section{2. Yield components and fresh fruit yield}

Fruit development started at about five weeks after sowing in all plots receiving NPK, poultry manure, compost and their combination and it continued till the end of the data collection. Length of fruit, fruit circumference and fresh weight fruit ${ }^{-1}$ of ladies finger were in the ranges from 10.42 to $11.79 \mathrm{~cm}, 4.91$ to 5.12 $\mathrm{cm}$ and 9.84 to $10.50 \mathrm{~g}$, respectively (Table 3 ). The lowest length of fruit, fruit circumference and fresh weight fruit $^{-1}$ was obtained with control treatment T1. However, application of poultry manure, kitchen compost and NPK fertilizer did not increase significantly fruit length, fruit circumference and fresh weight fruit $^{-1}$ from those of the control.

Number of fruits plant ${ }^{-1}$ is the most important yield attributing character of ladies finger. Number of fruits plant ${ }^{-1}$ ranged from 15.30 to 34.33 (Table 3). The lowest number of fruits plant ${ }^{-1}$ was found with treatment $\mathrm{T} 1$ (control) and the highest number of fruits plant ${ }^{-1}$ was observed at treatment $\mathrm{T} 4(50 \% \mathrm{NPK}+50 \%$ PM). Number of fruits plant ${ }^{-1}$ in treatment T4 $(34.33 ; 50 \% \mathrm{NPK}+50 \% \mathrm{PM})$ was statistically similar with treatment T3 (30.83; full PM) but significantly higher than treatment T1 (15.30; control) and T2 (17.97; full NPK). Treatment T2 (17.97; full NPK), T5 (22.03; full compost) and T6 (26.00; 50\% NPK+50\% compost) did not differ significantly from treatment T1 (15.30; control) and were statistically similar with each other in producing number of fruits plant $^{-1}$ though these treatments were either individual or combination of NPK fertilizer and compost.

Fresh fruit yield of ladies finger grown under different treatments varied from 4.29 to 7.98 ton $\mathrm{ha}^{-1}$ (Table 3). The highest fresh fruit yield was obtained with treatment T3 (full PM) and the lowest yield was found with control treatment (T1). Application of full NPK fertilizer $\left(4.71\right.$ ton $\left.\mathrm{ha}^{-1} ; \mathrm{T} 2\right)$ did not increase fresh fruit yield compared to control (4.29 ton ha $\left.{ }^{-1} ; \mathrm{T} 2\right)$. Fresh fruit yield in full poultry manure $\left(7.98\right.$ ton ha $\left.^{-1} ; \mathrm{T} 3\right)$ and $50 \%$ NPK $+50 \%$ PM $\left(7.95\right.$ ton ha- ${ }^{1}$; T4) were statistically similar with each other but were significantly higher than in control (4.29 ton ha ${ }^{-1}$; T1) and full NPK (4.71 ton ha ${ }^{-1}$; T2). Full compost (6.61 ton ha ${ }^{-1}$; T5) and 50\% NPK $+50 \%$ compost $\left(6.65\right.$ ton ha ${ }^{-1} ;$ T6) produced statistically similar amount of fresh fruit yields those were significantly higher than control $\left(4.29\right.$ ton ha $\left.^{-1} ; \mathrm{T} 1\right)$ and full NPK fertilizer $\left(4.71\right.$ ton ha $\left.^{-1} ; \mathrm{T} 2\right)$ but lower than full poultry manure (7.98 ton $\left.\mathrm{ha}^{-1} ; \mathrm{T} 3\right)$ and $50 \%$ NPK fertilizer $+50 \%$ PM $\left(7.95\right.$ ton ha- $\left.{ }^{1} ; \mathrm{T}^{-1}\right)$.

Table 3. Effects of poultry manure, kitchen compost and NPK fertilizer on yield components and fresh fruit yield of ladies finger.

\begin{tabular}{cllllll}
\hline Treatment & $\begin{array}{l}\text { Fruit } \\
\text { Length } \\
(\mathrm{cm})\end{array}$ & $\begin{array}{l}\text { Fruit circum- } \\
\text { ference }(\mathrm{cm})\end{array}$ & $\begin{array}{l}\text { Fresh } \\
\text { weight } \\
\text { fruit }^{-1}(\mathrm{~g})\end{array}$ & $\begin{array}{l}\text { Number of } \\
\text { fruits plant }^{-1}\end{array}$ & $\begin{array}{l}\text { Fresh fruit } \\
\text { yield } \\
\left.\text { ton ha }^{-1}\right)\end{array}$ & $\begin{array}{l}\text { Yield } \\
\text { increase } \\
(\%)\end{array}$ \\
\hline T1 & $10.42 \mathrm{a}$ & $4.91 \mathrm{a}$ & $9.84 \mathrm{a}$ & $15.30 \mathrm{c}$ & $4.29 \mathrm{c}$ & $0.00 \mathrm{c}$ \\
$\mathrm{T} 2$ & $11.15 \mathrm{a}$ & $5.09 \mathrm{a}$ & $10.08 \mathrm{a}$ & $17.97 \mathrm{bc}$ & $4.71 \mathrm{c}$ & $9.75 \mathrm{c}$ \\
$\mathrm{T} 3$ & $11.79 \mathrm{a}$ & $5.01 \mathrm{a}$ & $10.50 \mathrm{a}$ & $30.83 \mathrm{ab}$ & $7.98 \mathrm{a}$ & $85.90 \mathrm{a}$ \\
$\mathrm{T} 4$ & $10.86 \mathrm{a}$ & $5.11 \mathrm{a}$ & $10.11 \mathrm{a}$ & $34.33 \mathrm{a}$ & $7.95 \mathrm{a}$ & $85.32 \mathrm{a}$ \\
T5 & $10.79 \mathrm{a}$ & $5.11 \mathrm{a}$ & $10.32 \mathrm{a}$ & $22.03 \mathrm{abc}$ & $6.61 \mathrm{~b}$ & $54.04 \mathrm{~b}$ \\
T6 & $11.06 \mathrm{a}$ & $5.12 \mathrm{a}$ & $9.92 \mathrm{a}$ & $26.00 \mathrm{abc}$ & $6.65 \mathrm{~b}$ & $55.01 \mathrm{~b}$ \\
Sig. of F value & NS & NS & NS & 0.05 & 0.001 & 0.001 \\
\hline
\end{tabular}

Mean values in a column followed by the same letter $(\mathrm{s})$ are not significantly different by DMRT $(\mathrm{p}<0.05)$, NS= Not Significant.

Yield increase in treatment T3 (85.90\%; full PM) and T4 (85.32\%; 50\% NPK+50\% PM) over treatment T1 (control) was statistically similar but significantly higher than that in treatment T1 (control) (Table 3). Treatment T2 (9.75\%; full NPK) did not differ significantly from the control treatment. Yield increase in 
treatment T5 (54.04\%; full compost) and T6 (55.01; 50\% NPK+50\% compost) were also statistically similar but significantly higher than $\mathrm{T} 1$ (control) and lower than $\mathrm{T} 3$ and $\mathrm{T} 4$.

The results of the present study indicated that the experimental soil was very poorly fertile, and profitable crop growing without fertilizer application is not feasible there. Application of poultry manure and kitchen compost enhanced plant growth and development when compared to untreated controls and that resulted in higher yields of the crop. The highest yield $\left(7.98\right.$ ton ha $\left.^{-1}\right)$ was obtained in full poultry manure $\left(30\right.$ ton ha $\left.\mathrm{h}^{-1}\right)$. This treatment increased yield of ladies finger by $85.90 \%$ followed by $85.32 \%$ with $50 \% \mathrm{NPK}+50 \% \mathrm{PM}$ over the control (no fertilizer + no PM+ no compost). Full compost $\left(30\right.$ ton ha $\left.{ }^{-1}\right)$ also increased yield but by $54.04 \%$. The treatment $50 \% \mathrm{NPK}+50 \%$ compost increased yield by $55.01 \%$. Application of organic materials resulted in yield which compared favorably with NPK fertilizer alone.

Application of 50\% NPK+50 PM proved most effective in ensuring good performance in terms of growth and fresh fruit yield of ladies finger in valley soils of Chittagong, Bangladesh. In agreement with these results, Akande et al. [26] reported that combined use of ground rock phosphate applied together with poultry manure significantly improved growth and yield of Okra (Abelmoschus esculentus L Moench) compared to application of each material separately. Poultry manure has long been recognized as the most desirable organic fertilizer. It improves soil fertility by adding both major and essential nutrients as well as soil organic matter which improve moisture and nutrient retention [27]. Olaniyi et al. [28] reported that growth of okra (ladies finger) plant was markedly influenced by the application of organomineral, NPK fertilizer and their combination as observed from the increased plant height and number of leaves compared to control. They observed a great increase in yield of okra when NPK fertilizer was combined with organomineral fertilizer. Palm et al. [29] gave the importance of organic and inorganic fertilizer as essential tools in okra production. The low response of ladies finger to NPK fertilizer in the present study as compared to combined application of NPK fertilizer with poultry manure or compost corroborates the response patterns reported by other researchers on okra [30] and on maize crop [31]. Poultry manure alone and in combination with NPK fertilizer gave higher plant height, number of fruits plant ${ }^{-1}$ and fresh fruit yield than compost combination and NPK alone. One of the objectives of the present study was to observe the efficiency of composts prepared from kitchen wastes in increasing yield of crops. Compost (30 ton ha $\mathrm{h}^{-1}$ ) and partial compost and NPK fertilizers increased growth and yield of ladies finger over control but not to the same extent as poultry manure.

\section{Conclusion}

Application of poultry manure and kitchen waste compost alone or in combination in the poorly fertile valley soils of Chittagong enhanced growth and yield of ladies finger. Application of poultry manure and kitchen compost combined with NPK fertilizer will reduce the farmer's budget for crop fertilization and inclusion of poultry manure and kitchen compost in the combination will surely ensure production of crops under a less polluted environment.

\section{References}

[1] C. Gopalan, S. B.V. Sastri, S. Balasubramanian, Nutritive value of Indian foods (India, National Institute of Nutrition, ICMR, 2007)

[2] P. Arapitsas, Identification and quantification of polyphenolic compounds from okra seeds and skins, Food Chemistry, 110, 2008, 1041-1045

[3] S. Dilruba, M. Hasanuzzaman, R. Karim, K. Nahar, Yield response of okra to different sowing time and application of growth hormones, Journal of Horticultural Science and Ornamental Plants, 1, 2009, 10-14.

[4] S. Benchasri, Okra (Abelmoschus esculentus L. Moench) as a Valuable Vegetable of the World. Ratar. Povrt. 49, $2012,105-112$

[5] J. A. Akinfasoye and E. I. Nwanguma, Vegetative growth of telfaria occidentalis Hoof, F and staking pattern in telfaria/okra intercrop in a valley bottom dry season cultivation, Proc. Horticultural Society of Nigeria Annual Conference, Rivers State College of Education, Portharcourt, 2005, 67-71.

[6] V. Varmudy, Marking survey need to boost okra exports (India, Department of economics, Vivekananda College, Karnataka, 2011)

[7] BBS (Bangladesh Bureau of Statistics), Monthly Statistical Bulletin Bangladesh, April (Statistic Division, Ministry of Planning, Government of Bangladesh, 2000).

[8] S. M. Hossain (Ed.), Modern varieties of vegetables and cultivation methods (Horticulture Research Centre, Bangladesh Agricultural Research Institute, 2000)

[9] N. I. Bhuiyan, Soil research in Bangladesh: past, present and future, Proceedings on SoilResearch and Education in Bangladesh, BAU, Mymensingh, 1998, 1-6.

[10] G. Gonlaïna, Indicators and management of soil fertility by farmers in Yagoua region (Far-North/Cameroon), Maîtrise dissertation, Department of Biological Sciences, University of Ngaoundéré33, 2002.

[11] M. S. Islam. Use of bio slurry as organic fertilizer in Bangladesh agriculture, Proceedings of the International Workshop on the Use of Bio slurry Domestic Biogas Program, Bangkok, Thailand, 2006.

[12] O. Olatunji, S. A. Ayuba and V. U. Oboh, Growth and yield of okra and tomato as affected by pig dung and other organic manures: Issues for economic consideration in Bane state, Proceedings of the 30th Annual Conference of the Soil Science Society of Nigeria, University of Agriculture, Markudi, 2006, 91- 98.

[13] G. Corrale, A. Guerra and F. Montes de Oca, Potassium fertilization effect on yield and its components in banana vicands in a brown with carbonates soil ciencia. Technica enla Agriculture, 13, 1990, 7-16.

[14] G. A. Thomas, Toxicity identification of poultry litter aqueous leachate, Soil Fertilizer, 8(1), 1997, $251-252$.

[15] F.N. Ikpe and J. M. Powel, Nutrient cycling practices and changes in soil properties in the coop-livestock farming systems of Western Nigeria, Republic of West Africa, Nutrient Cycling Agroecosystem, 62, 2002, 37-45. 
[16] B. S. Ewulo, Effect of poultry and cattle manure on sandy clay loam soil, Journal of animal and Veterinary Science, 4, 2005, 839841.

[17] L. Van-Camp, B. Bujarrabal, A. R. Gentile, R.J.A. Jones, L. Montanarella, C. Olazabal, S. K. Selvaradjou, Organic matter and biodiversity - Volume III . Reports of the Technical Working Groups established under the Thematic Strategy for Soil Protection, EUR 21319 EN/3, (Luxembourg, Official Publications of the European Communities, 2004).

[18] S. Last, An introduction to waste technologies (Waste Technologies UK Associates, 2006).

[19] BARC (Bangladesh Agricultural Research Council), Fertilizer Recommendation Guide (Dhaka, BARC Soils Publications No 45, 2005).

[20] P. R. Day, Particle fractionation and particle size analysis, in C. A. Black (Ed.) Methods of Soil Analysis. Part I. Agronomy Monograph, (New York: Academic Press, 1965) 545-567.

[21] A. Walkley and I. A. Black, An examination of the Degtjareff method for determining organic carbon in soils: Effect of variations in digestion conditions and of inorganic soil constituents, Soil Science, 63, 1934, 251-263.

[22] M L. Jackson, Soil Chemical Analysis (New Delhi, Prentice Hall of India Private Limited, 1973).

[23] S. Olsen, C. Cole, F. Watanabe and L. Dean, Estimation of available phosphorus in soils by extraction with sodium bicarbonate (USDA Circular No. 939, US Government Printing Office, Washington, D.C., 1954).

[24] Excel Inc., Microsoft Excel for Windows (USA, Microsoft Corporation, 2003).

[25] SPSS Inc., Statistics (Chicago, SPSS Inc. 2003).

[26] M. O. Akande, F. I. Oluwatoyinbo, J. A. Adediran, K. W. Buari and I. O. Yusuf, Soil amendments affect the release of P from rock phosphate and the development and yield of okra, Journal of Vegetable Crop Production, 9(2), 2003, 3-9.

[27] W. Farhad, M.F. Saleem, M.A Cheema and H. M. Hammad, Effect of poultry manure levels on the productivity of spring maize (Zea mays L.), Journal of Animal and Plant Science, 19 (3), 2009, 122-125.

[28] J. O. Olaniyi, W. B. Akanbi, O. A. Olaniran and O. T. Ilupeju, The effect of organo-mineral and inorganic fertilizers on the growth, fruit yield, quality and chemical compositions of okra, Journal of Animal \& Plant Sciences, 9(1), 2010, 1135-1140.

[29] C. A Palm, J. K. Myer and S. M. Nandwa, Combined use of organic and inorganic nutrient sources for soil fertility maintenance and replenishment (Soil Science Society of America Special Publication 51, 1997)

[30] W. B Akanbi, A. O. Togun, J. A Adediran, A. B Olaniyan, O. S Olabo de, and J. O Olaniyi, Effect of split application of organomineral fertilizer on Okra growth, nutrient uptake and fruit yield, Nigerian Journal of Horticultural Science, 9, 2000, 102-109.

[31] J. O. Olaniyi, J. O. Ogunrinde, O. S. Olabode, W. B. Akanbi, Effect of organic mineral fertilizer application on growth, yield and nutrient uptake of Maize, Journal of Applied Agricultural and Apicultural Research, 2(1), 2005,10-19. 